\title{
Gender Wise Livelihood Pattern of Various Categories of Farm Families
}

\author{
Suchitra* and Sushma Kaushik \\ Department of Extension Education and Communication Management, CCS HAU, \\ Hisar, Haryana, India \\ *Corresponding author
}

Ke y w o r d s
Livelihood pattern,
Categories,
$\begin{aligned} & \text { Families, } \\ & \text { Agriculture }\end{aligned}$
Article Info
$\begin{aligned} & \text { Accepted: } \\ & \text { 26 December } 2017 \\ & \text { Available Online: } \\ & \text { 10 January } 2018\end{aligned}$

\section{Introduction}

For the developing countries like India, where a majority of families, in both the farm and non-farm sectors, derive their livelihoods from agriculture, sustainability of agriculture cannot be discussed or even defined in isolation of the issue of livelihoods. Livelihood is defined as adequate stock and flow of food and cash with an individual or a family to meet its basic needs.

Livelihoods are the ways in which people satisfy their needs, or gain a living. The term

\begin{abstract}
The present study was conducted in four districts of Haryana state. Total 300 household rom different landholding categories were selected from four villages of the selected ts. The findings of the study revealed that majorities of landless male as well as tabour either in agriculture or in non-agriculture. man days) followed by self-employed in non- agricultural (180 man days). Most of marginal land holding farmers were causal labours in agriculture, while females' member most equally worked as causal labour in agriculture and self-employed in agriculture. Maximum time of males was spent as causal labour in non-agriculture (200 man days), medium and large land holding males were self-employed in agriculture in both the zones. Maximum time devoted by these categories was also as self-employed in agriculture by small (210 man days), (250 man days) and large (180 man days) make farmers. Similar trend was observed for females, though they were spending lesser time in these activities.

A B S T R A C T
\end{abstract}

is well recognized as humans inherently develop and implement strategies to ensure their survival. Livelihood analysis looks at the different kinds of household activities and the contribution of each one to make the household livelihood. An individual may take on several activities to meet his/her needs. One or many individuals may engage in activities that contribute to a collective livelihood strategy. Within households, individuals often take on different responsibilities to enable the sustenance and growth of the family. Women play a pivotal role in the family and the community, 
shouldering several household responsibilities. They constitute a significant proportion of unpaid family workers, though in many instances, women are also engaged as paid workers. Women, in particular, constitute a significant proportion of unpaid family helpers. For example, unpaid work on family agricultural enterprises accounts for 34 percent of women's informal employment in India (compared with 11 percent of men's informal employment) and for an astounding 85 percent in Egypt (compared with 10 percent for men) (UNIFEM, 2005). Women and men working in rural setting are often involved in multiple activities and different contractual arrangements simultaneously. Rural employment includes farming, selfemployment working in trade, small enterprises providing goods and services, wage labour in these and wage labour in agriculture. Some of this work involves long hours and is not sufficiently remunerated. Women, in particular, constitute a significant proportion of unpaid family workers. Women and men working in rural settings are often involved in multiple activities and different contractual arrangements simultaneously. They may need to change jobs, depending on the season, or may remain unemployed or underemployed for periods of time. Agriculture continues to be the main source of rural employment for both women and men in India.

\section{Materials and Methods}

The present study was conducted in Haryana state. The Haryana state is divided into two zones viz. Eastern zone and Western zone. Out of each zone, two districts were selected randomly viz. Panipat and Karnal from Eastern zone and Hisar and Sirsa from Western zone. From each selected district, one village was selected randomly, thus making a total of four villages. Seventy five respondents from each selected villages were drawn randomly representing various land holding categories (15 each from landless, marginal, small, medium and large). Thus, a total sample of three hundred households was taken for the study. A well-structured pre -tested interview schedules was constructed for the study. Data were collected personally from heads of households. Frequency and percentages were computed.

\section{Results and Discussion}

Gender wise distribution of landless families according to nature and duration of work

Distribution of landless families according to nature and hours of work has been presented in Table 1. A perusal of table clearly depict that majority of the male members in Eastern zone were working as causal labour in agriculture $(83.3 \%)$ followed by causal labour in non-agriculture $(63.3 \%)$. Only few landless respondents in Eastern zone were selfemployed in non-agriculture $(6.7 \%)$ and salaried employees in government $(3.3 \%)$.

Regarding time spent, other than service (where working hours all most fixed) maximum time was spent as causal labour in non-agriculture (244 man days) followed by self-employed in non- agricultural (180 man days) and causal labour in agricultural (155 man days). Similar trend was observed for females though they were spending less time as compared to males in all the three activities.

Similarly about half of the females in Eastern zone were engaged as causal labour in agriculture $(53.3 \%)$ and causal labour in nonagriculture (43.3\%). Only 16.7 per cent females were self-employed in nonagriculture. As far as Western zone was concerned, again most of the landless male members worked as causal labour in agriculture $(90 \%)$ followed by causal labor in 
non-agriculture $(70 \%)$. Similar trend was observed for women. Sreedevi (2013) estimated that most of the farmers basically were dependent on agriculture i.e., 74.96 per cent in Kistapur and 57.23 per cent in Powerguda village for their livelihoods. The second source of livelihoods in both the villages was agricultural labour wages (about $17.22 \%$ in Powerguda and $7.97 \%$ in Kistapur).

Non-agricultural wage labour was ranked third as sources of livelihoods in Kistapur village with 4.78 per cent and 2.78 per cent in Powerguda ranked six. Again except service, maximum time of males as well as females was spent on causal labour in non-agriculture (250 and 200 man days respectively) followed by self-employed in non agri. (160 and 180 man days respectively) and causal labour in agriculture (96 and 65 man day respectively).

In aggregate, majority of males as well as females in both the zones were working as casual labour either in agriculture or in nonagriculture, and maximum time devoted was as causal labour in non-agriculture by both males and females in both the zones.

Gender wise distribution of marginal farm families according to nature and duration of work

Distribution of marginal farm families according to nature and duration of work has been presented in Table 2. Analysis of table reveals that most of the male members in Eastern zone were working as causal labour in agriculture (43.3\%) though 36.7 per cent were self-employment in agriculture. 23.3 per cent of respondents in Eastern zone were selfemployed in non-agriculture and causal labour in non-agriculture each. As regards females in Eastern zone, again about one third was engaged as causal labour in agriculture (33.3\%) and self-employed in agriculture $(30 \%)$.
Apart from service males in Eastern zone spent maximum time as causal labour in nonagriculture (200 man days) followed by selfemployed in non-agriculture (150 man days) self-employed in agriculture (180 man days) causal labour in agriculture (60 man days), similar trend was observed in females but they were spending lesser time in all the activities accept that they were spending more time as self-employed in non- agriculture.

As far as Western zone was concerned, majority of male members of marginal farm families were working as causal labour in agriculture $(70 \%)$ followed by causal labour in non-agriculture $(36.7 \%)$ and self-employed in agriculture (33.3\%). Regarding females in Western zone, less than half of them were self-employed in agriculture $(46.7 \%)$ while one third were working as causal labour $(33.3 \%)$.

It was interesting to note that more women were self-employed in agriculture as compared to men, it may be because their land holdings were small and unsustainable, and therefore, they had to work outside for earning income. Sharma (2010) showed that a large majority of the households whose main source of income was other than cultivation belonged to the categories possessing less than one hectare of land. Since, these households do not possess sufficient land, cultivation does not provide adequate income for them; they are obliged to depend on wage/ salaried employment, non-agricultural enterprises and other sources of income for their livelihood.

Regarding time, results showed that maximum time of males as well as females was spent as self-employed in agriculture (190 and 170 man days respectively) followed by selfemployed in non-agriculture (130 and 150 man days respectively), causal labour in nonagriculture (180 and 120 man days respectively). 
Table.1 Gender wise distribution of landless families according to nature and duration of work

\begin{tabular}{|c|c|c|c|c|c|c|c|c|c|}
\hline \multirow{3}{*}{ SN. } & \multirow{2}{*}{$\begin{array}{l}\text { Variables and } \\
\text { Categories }\end{array}$} & \multicolumn{4}{|c|}{ Eastern Zone (n=30) } & \multicolumn{4}{|c|}{ Western Zone (n=30) } \\
\hline & & Males & $\begin{array}{l}\text { Avg. } \\
\text { Man } \\
\text { Day/ } \\
\text { Annum }\end{array}$ & Females & $\begin{array}{l}\text { Avg. Man } \\
\text { Day/ } \\
\text { Annum }\end{array}$ & Males & $\begin{array}{l}\text { Avg. } \\
\text { Man } \\
\text { Day/ } \\
\text { Annum }\end{array}$ & Females & $\begin{array}{c}\text { Avg. } \\
\text { Man } \\
\text { Day/ } \\
\text { Annum }\end{array}$ \\
\hline & $\begin{array}{l}\text { Employment } \\
\text { status }\end{array}$ & $\mathbf{F}(\%)$ & & F $(\%)$ & & F $(\%)$ & & F $(\%)$ & \\
\hline 1. & $\begin{array}{l}\text { Causal labour } \\
\text { in agriculture }\end{array}$ & $25(83.3)$ & 155 & $16(53.3)$ & 80 & $27(90.0)$ & 96 & $22(50.0)$ & 65 \\
\hline 2. & $\begin{array}{l}\text { Self-employed } \\
\text { in non- } \\
\text { agriculture }\end{array}$ & $2(6.7)$ & 180 & $5(16.7)$ & 150 & $1(3.3)$ & 160 & $2(6.7)$ & 180 \\
\hline 3. & $\begin{array}{l}\text { Causal labour } \\
\text { in non- } \\
\text { agriculture }\end{array}$ & $19(63.3)$ & 244 & $17(43.3)$ & 180 & $21(70.0)$ & 250 & $14(46.7)$ & 200 \\
\hline 4. & Salaried govt. & $1(3.3)$ & 270 & $0(0.0)$ & 0 & $4(13.3)$ & 272 & $1(3.3)$ & 260 \\
\hline 5. & $\begin{array}{l}\text { Salaried } \\
\text { private }\end{array}$ & $0(0.0)$ & 0 & $0(0.0)$ & 0 & $1(3.3)$ & 273 & $0(0.0)$ & \\
\hline
\end{tabular}

Source: World Development Report (2008)

Table.2 Gender wise distribution of marginal farm families according to nature and Duration of work

\begin{tabular}{|c|c|c|c|c|c|c|c|c|c|}
\hline \multirow{3}{*}{ SN. } & \multirow{2}{*}{$\begin{array}{l}\text { Variables and } \\
\text { Categories }\end{array}$} & \multicolumn{4}{|c|}{ Eastern Zone (n=30) } & \multicolumn{4}{|c|}{ Western Zone (n=30) } \\
\hline & & Males & $\begin{array}{c}\text { Avg. } \\
\text { Man } \\
\text { Day/ } \\
\text { Annum }\end{array}$ & Females & $\begin{array}{c}\text { Avg. } \\
\text { Man } \\
\text { Day/ } \\
\text { Annum }\end{array}$ & Males & $\begin{array}{c}\text { Avg. } \\
\text { Man } \\
\text { Day/ } \\
\text { Annum }\end{array}$ & Females & $\begin{array}{l}\text { Avg. } \\
\text { Man } \\
\text { Day/ } \\
\text { Annum }\end{array}$ \\
\hline & $\begin{array}{l}\text { Employment } \\
\text { status }\end{array}$ & $\mathbf{F}(\%)$ & & $\mathbf{F}(\%)$ & & $\mathbf{F}(\%)$ & & $\mathbf{F}(\%)$ & \\
\hline 1. & $\begin{array}{l}\text { Self-employed in } \\
\text { agriculture }\end{array}$ & $11(36.7)$ & 180 & $9(30.0)$ & 150 & $10(33.3)$ & 190 & $14(46.7)$ & 170 \\
\hline 2. & $\begin{array}{l}\text { Causal labour in } \\
\text { agriculture }\end{array}$ & $13(43.3)$ & 60 & $10(33.3)$ & 50 & $21(70.0)$ & 80 & $10(33.3)$ & 70 \\
\hline 3. & $\begin{array}{l}\text { Self-employed in } \\
\text { non-agriculture }\end{array}$ & $7(23.3)$ & 150 & $4(13.3)$ & 180 & $6(20.0)$ & 130 & $3(10.0)$ & 150 \\
\hline 4. & $\begin{array}{l}\text { Causal labour in } \\
\text { non-agriculture }\end{array}$ & $7(23.3)$ & 200 & $6(20.0)$ & 150 & $11(36.7)$ & 180 & $9(30.0)$ & 120 \\
\hline 5. & Salaried (govt.) & $2(6.7)$ & 270 & $0(0.0)$ & 0 & $1(3.3)$ & 273 & $0(0.0)$ & 0 \\
\hline 6. & Salaried (private) & $1(3.3)$ & 280 & $0(0.0)$ & 0 & $0(0.0)$ & 0 & $0(0.0)$ & 0 \\
\hline
\end{tabular}


Table.3 Gender wise distribution of small farm families according to nature and Duration of work

\begin{tabular}{|c|c|c|c|c|c|c|c|c|c|}
\hline \multirow{3}{*}{ SN. } & \multirow{2}{*}{$\begin{array}{l}\text { Variables } \\
\text { and } \\
\text { Categories }\end{array}$} & \multicolumn{4}{|c|}{ Eastern Zone (n=30) } & \multicolumn{4}{|c|}{ Western Zone (n=30) } \\
\hline & & Males & $\begin{array}{c}\text { Avg. } \\
\text { Man } \\
\text { Day/ } \\
\text { Annum }\end{array}$ & Females & $\begin{array}{l}\text { Avg. } \\
\text { Man } \\
\text { Day/ } \\
\text { Annum }\end{array}$ & Males & $\begin{array}{c}\text { Avg. } \\
\text { Man } \\
\text { Day/ } \\
\text { Annum }\end{array}$ & Females & $\begin{array}{l}\text { Avg. } \\
\text { Man } \\
\text { Day/ } \\
\text { Annum }\end{array}$ \\
\hline & $\begin{array}{l}\text { Employment } \\
\text { status }\end{array}$ & $\mathbf{F}(\%)$ & & $\mathbf{F}(\%)$ & & $\mathbf{F}(\%)$ & & $\mathbf{F}(\%)$ & \\
\hline 1. & $\begin{array}{l}\text { Self- } \\
\text { employed in } \\
\text { agriculture }\end{array}$ & $\begin{array}{c}27 \\
(90.0)\end{array}$ & 210 & $20(66.7)$ & 160 & $\begin{array}{c}28 \\
(93.3)\end{array}$ & 240 & $17(56.7)$ & 180 \\
\hline 2. & $\begin{array}{l}\text { Self- } \\
\text { employed in } \\
\text { non- } \\
\text { agriculture }\end{array}$ & $6(20.0)$ & 120 & $5(16.7)$ & 150 & $10(33.3)$ & 90 & $8(26.7)$ & 120 \\
\hline 3. & $\begin{array}{l}\text { Salaried } \\
\text { (govt.) }\end{array}$ & $5(16.7)$ & 272 & $1(3.3)$ & 270 & $3(10.0)$ & 274 & $1(3.3)$ & 271 \\
\hline 4. & $\begin{array}{l}\text { Salaried } \\
\text { (private) }\end{array}$ & $2(6.7)$ & 275 & $0(0.0)$ & & $1(3.3)$ & 280 & $0(0.0)$ & \\
\hline
\end{tabular}

Table.4 Gender wise distribution of medium land holding households according to nature and duration of work

\begin{tabular}{|c|c|c|c|c|c|c|c|c|c|}
\hline \multirow[t]{3}{*}{$\mathbf{S N}$} & Variables & \multicolumn{4}{|c|}{ Eastern Zone $(\mathrm{n}=30)$} & \multicolumn{4}{|c|}{ Western Zone (n=30) } \\
\hline & $\begin{array}{l}\text { and } \\
\text { Categories }\end{array}$ & Male & $\begin{array}{c}\text { Avg. } \\
\text { Man } \\
\text { Day/ } \\
\text { Annum }\end{array}$ & Females & $\begin{array}{l}\text { Avg. } \\
\text { Man } \\
\text { Day/ } \\
\text { Annum }\end{array}$ & Males & $\begin{array}{l}\text { Avg. } \\
\text { Man } \\
\text { Day/ } \\
\text { Annum }\end{array}$ & Females & $\begin{array}{l}\text { Avg. } \\
\text { Man } \\
\text { Day/ } \\
\text { Annum }\end{array}$ \\
\hline & $\begin{array}{l}\text { Employment } \\
\text { status }\end{array}$ & $\begin{array}{c}F \\
(\%)\end{array}$ & & $\mathbf{F}(\%)$ & & F $(\%)$ & & $\mathbf{F}(\%)$ & \\
\hline 1. & $\begin{array}{l}\text { Self- } \\
\text { employed in } \\
\text { agriculture }\end{array}$ & $\begin{array}{c}26 \\
(86.7)\end{array}$ & 220 & $\begin{array}{c}12 \\
(40.0)\end{array}$ & 120 & $\begin{array}{c}30 \\
(100)\end{array}$ & 250 & $\begin{array}{c}1 \\
6(53.3)\end{array}$ & 180 \\
\hline 2. & $\begin{array}{l}\text { Self- } \\
\text { employed in } \\
\text { non- } \\
\text { agriculture }\end{array}$ & $2(6.7)$ & 180 & $1(3.3)$ & 90 & $\begin{array}{c}5 \\
(16.7)\end{array}$ & 160 & $2(6.7)$ & 90 \\
\hline 3. & $\begin{array}{l}\text { Salaried } \\
\text { govt. }\end{array}$ & $\begin{array}{c}7 \\
(23.3)\end{array}$ & 270 & $1(3.3)$ & 271 & $\begin{array}{c}5 \\
(16.7)\end{array}$ & 273 & $2(6.7)$ & 272 \\
\hline 4. & $\begin{array}{l}\text { Salaried } \\
\text { private }\end{array}$ & $\begin{array}{c}3 \\
(10.0)\end{array}$ & 275 & $0(0.0)$ & 0 & $\begin{array}{c}4 \\
(13.3)\end{array}$ & 280 & $0(0.0)$ & 0 \\
\hline
\end{tabular}


Table.5 Gender wise distribution of large land holding households according to nature and duration of work

\begin{tabular}{|c|c|c|c|c|c|c|c|c|c|}
\hline \multirow[t]{3}{*}{$\mathbf{S N}$} & \multirow{2}{*}{$\begin{array}{l}\text { Variables } \\
\text { and } \\
\text { Categories }\end{array}$} & \multicolumn{4}{|c|}{ Eastern Zone $(\mathrm{n}=30)$} & \multicolumn{4}{|c|}{ Western Zone (n=30) } \\
\hline & & Males & $\begin{array}{c}\text { Avg. } \\
\text { Man } \\
\text { Day/ } \\
\text { Annum }\end{array}$ & Females & $\begin{array}{c}\text { Avg. } \\
\text { Man } \\
\text { Day/ } \\
\text { Annum }\end{array}$ & Males & $\begin{array}{c}\text { Avg. } \\
\text { Man } \\
\text { Day/ } \\
\text { Annum }\end{array}$ & Females & $\begin{array}{l}\text { Avg. } \\
\text { Man } \\
\text { Day/ } \\
\text { Annum }\end{array}$ \\
\hline & $\begin{array}{l}\text { Employment } \\
\text { status }\end{array}$ & $\mathbf{F}(\%)$ & & F $(\%)$ & & $\mathbf{F}(\%)$ & & F (\%) & \\
\hline 1. & $\begin{array}{l}\text { Self- } \\
\text { employed in } \\
\text { agriculture }\end{array}$ & $24(80.0)$ & 150 & $10(33.3)$ & 60 & $26(86.7)$ & 180 & $13(43.3)$ & 90 \\
\hline 2. & $\begin{array}{l}\text { Self- } \\
\text { employed in } \\
\text { non- } \\
\text { agriculture }\end{array}$ & $2(6.7)$ & 180 & $2(6.7)$ & 120 & $3(10.0)$ & 120 & $2(6.7)$ & 90 \\
\hline 3. & $\begin{array}{l}\text { Salaried } \\
\text { govt. }\end{array}$ & $6(20.0)$ & 271 & $2(6.7)$ & 273 & $8(26.7)$ & 270 & $4(13.3)$ & 272 \\
\hline 4 & $\begin{array}{l}\text { Salaried } \\
\text { private }\end{array}$ & $4(13.3)$ & 280 & $0(0.0)$ & 0 & $6(20.0)$ & 282 & $0(0.0)$ & 0 \\
\hline
\end{tabular}

Thus, it can be concluded that most of male members in Eastern as well as Western zone were causal labours in agriculture, while females member almost equally worked as causal labour in agriculture and self-employed in agriculture. In Western zone, most of females were self- employed in agriculture. The farmers in Western zone devoted more time as self-employed in agriculture as compared to Eastern zone. Females were devoting more time as self-employed in nonagriculture in both the zones.

Gender wise distribution of small farm families according to nature and duration of work

The data pertaining to nature and duration of work perused by small farm families reported in Table 3 elucidate that the majority of the male members in both Eastern as well as Western zones were self-employed in agriculture (90\% and $93.3 \%$ respectively) while about one fifth of respondents in Eastern zone and one third in Western zone were self-employed in non-agriculture. About 16.7 per cent males in Eastern zone 10 per cent in Western zone were salaried employees either in Govt. or in private sector. Salman and Munir (2016) revealed that there were almost one third landless people in almost every village and the marginal and small landholders constitute about 90 per cent of the total landholders. The largest share of the respondents was found to be engaged in crop cultivation $(37.95 \%)$ followed by agricultural labour (19.73\%), animal husbandry (17.11\%), other employments (13.44\%) and business/ job $(11.78 \%)$. Although, the share of people engaged in agricultural activities seemed to be less than 40 per cent but many farmers were practicing agriculture as their second or third occupation. Many marginal farmers started non-agricultural activities along with the traditional agriculture on their small piece of land.

As regard females, majority were selfemployed in agriculture both in Eastern $(66.7 \%)$ as well as Western zones $(56.7 \%)$ 
followed by self -employed in non-agriculture (16.7\% and $26.7 \%$ respectively). Only one female in each zone was govt. salaried employ while none of the female was employed in private sector. As regards time spent, maximum time of small farm families was devoted as selfemployed in agriculture in both Eastern (210 man days) as well as Western zone (240 man days) followed by self-employed in nonagriculture (120 and 90 man days respectively). Similar trend was observed in females, though they were spending more time as self-employed in non-agriculture compared to men. Thus, it can be determined that most of males as well as females in both the zones were self-employed in agriculture followed by self-employed in nonagriculture. The respondents in Western zone spent more time as self-employed in agriculture and lesser time as self-employed in nonagriculture compared to Eastern zone.

Gender wise distribution of medium land holding households according to nature and duration of work

Nature and hours of work perused by medium farm families according to gender has been presented in Table 4. Investigation of the table exposes that cent per cent males in Western zone and 86.7 per cent in Eastern zone were self-employed in agriculture.

About one fourth males were salaried govt. employees $(23.3 \%)$ and one tenth were salaried employees in private sector in Eastern zone, while 16.7 and 13.3 percent were in govt. and private sector each in salaried employee. Very few small farmers in Eastern zone as well as Western zone were self-employed in nonagriculture (6.7\% and $16.7 \%$ each). Regarding females in Eastern zone, 40 per cent were selfemployed in agriculture while 3.3 per cent each were self-employed in non-agriculture and salaried government.

Regarding females in Western zone, about half of them were self-employed in agriculture $(53.3 \%)$ while 6.7 per cent each were selfemployed in non-agriculture and salaried govt. Yishak et al., (2014) also observed that more proportion (84\%) of better-off households were engaged solely on farming, while only 23.4 per cent and about 48.6 per cent of poor and medium households respectively pursued the same activities. Non-farm activities played a crucial role in livelihood of the poor and medium households, which accounted about 39.3 per cent of poor and 43.8 per cent of medium households. As regards females among marginal farmers, it was interesting to note that more women were self-employed in agriculture as compared to men, may be because their land holdings were small and unsustainable and therefore they had to work outside for earning income.

As regards time spent, maximum time of males as medium farm families was devoted as selfemployed in agriculture in both Eastern (220 man days) as well as Western zone (250 man days) followed by self-employed in nonagriculture (180 and 160 man days respectively). Similar trend was observed for females.

Thus, it can be concluded that most of males in Eastern as well as Western zones were selfemployed in agriculture followed by salaried employees. The farmers in Western zone devoted more time as self-employed in agriculture, while in Eastern zone, maximum time was spent as self-employed in nonagriculture.

Gender wise distribution of large land holding households according to nature and duration of work

Distribution of large farm families according to nature and duration of work as presented in Table 5 reveals that most of the male members in Eastern zone as well as Western zone were working as self-employed in agriculture $(80 \%$ and $86.7 \%$ respectively) followed by Salaried government employees (20\%) and (26.7\%). As regards females, about one third was selfemployed in agriculture in both zone i.e. Eastern zone (33.3\%) and Western zone $(43.3 \%)$. Less than ten per cent males and 
females in both the zones were self-employed in non- agriculture.

It can be further seen from the table that 13.3 and 20 per cent males in Eastern and Western zones respectively were salaried employees in private sector while none of the females was employed in this sector, though few women were employed in Govt. sector.

Regarding time devoted 180 man days were spent by males as self-employed in nonagriculture in Eastern zone and as selfemployed in agriculture in Western zone. The females in Eastern zone spent maximum time as self-employed in non-agriculture (120 man days) followed by self-employed in agriculture (60 man days) while in Western zone the females were spending equal time in both the activities (90 man days each).

Thus, it can be concluded that most of males in Eastern as well as Western zones were selfemployed in agriculture whereas; self-employed females in agriculture were quite less as compared to males among large landholding farm families.

The findings of the study revealed that, majority of landless males as well as females in both the zones were working as casual labour either in agriculture or in non-agriculture, while majority of small, medium and large category of respondents were engaged in farming. As regards females among marginal farmers, it was interesting to note that more women were selfemployed in agriculture as compared to men, may be because their land holdings were small and unsustainable and therefore they had to work outside for earning income. As regards time devoted to various activities, the findings of present study revealed that landless and marginal respondents spent maximum time (about 200 man days) as casual labor in nonagriculture and as casual labor in agriculture. However, small and medium farmers spent more time as self- employed in agriculture as they were perusing farming on their own land. Large category also spent time as selfemployed in agriculture but they were devoting lesser time in agriculture as compared to small and medium farmers.

\section{References}

Salman, M. S. and Munir, A. 2016. Common land resources, livelihood and sustaining the rural poor in India, a geographical analysis. European Journal of Geography. 7(4): 6-18.

Sharma, R. 2010. Diversification in rural livelihood strategies: a macro-level evidence from Jammu and Kashmir. Working Papers can be downloaded from the Centre's website. http://www.cds.edu.

Sreedevi, T. K. 2013. Livelihoods analysis in Powerguda and Kistapur micro watersheds in Southern India. International Crops Research Institute for the Semi-Arid Tropics.www.icrisat. org.

UNIFEM. 2005. Progress of the World's Women 2005.UNIFEM.

Yishak, G. Ayele, G. Lemma, T., and Alemu, D. 2014. Rural household livelihood strategies: options and determinants in the case of Wolaita Zone, Southern Ethiopia. Social Sciences. 3(3): 92-10.

\section{How to cite this article:}

Suchitra and Sushma Kaushik. 2018. Gender Wise Livelihood Pattern of Various Categories of Farm Families. Int.J.Curr.Microbiol.App.Sci. 7(01): 355-362.

doi: https://doi.org/10.20546/ijcmas.2018.701.040 